\title{
THE FEATURES OF OCCUPATIONAL BURNOUT IN CIVIL SERVANTS
}

\author{
A. O. Ivanchuk, A. M. Kravchenko, K. O. Mikhaliev
}

State Institution of Science «Research and Practical Center of Preventive and Clinical Medicine» State Administrative Department, Kyiv, Ukraine

\section{Summary}

Aim: to study the presence and severity of the occupational burnout syndrome components in civil servants.

Material and methods. A group of 100 civil servants aged 30 to 60 (mean age $41 \pm 7.7$ years; 63 $(63 \%)$ males and 37 (37\%) females) were randomly selected and examined. All the enrolled people participated in the regular medical check-up programs, and were free from severe chronic conditions. The Ukrainian version of MBI was used to diagnose the burnout syndrome.

Results. In general, medium to high levels of professional burnout for all the burnout syndrome components (emotional exhaustion, depersonalization, reduction of professional achievements) were found in $86(86,0 \%)$ people. Among them, $11(12,8 \%)$ respondents had a high level of each of these three burnout syndrome indicators. Emotional exhaustion was the most frequent condition among the enrolled respondents (totally, $78(78 \%)$ people pointed at medium to high level of emotional exhaustion). Depersonalization was the second most common condition with $65 \%$ of respondents (65 people) having its medium to high level. Reduction of professional accomplishment (medium to high level) was less common and registered in $54(54 \%)$ respondents. Females, as compared to males, were more vulnerable to emotional exhaustion, presenting the higher average score ([median, interquartile range] 27 (20-33) vs. 19 (15-25), respectively; $\mathrm{p}<0,001)$, and the higher total frequency of medium to high level cases of that burnout syndrome component ( $89 \%$ vs. $72 \%$, respectively; $p=0,047$ ), namely due to more frequent latter ones ( $57 \%$ vs. $32 \%$, respectively; $p=0,027$ ). Conclusion. The high prevalence of occupational burnout, namely its medium to high severity level, among the civil servants has been established, which indicates the urgency of the problem and the necessity for further research to find the causes, effective prevention measures, and ways to overcome the syndrome and restore the mental and physical health of civil servants.

Key words: occupational burnout, civil servant, emotional exhaustion, depersonalization, reduction of professional accomplishment

\section{INTRODUCTION}

The professional activity of a civil servant is associated with a high level of psycho-emotional load, chronic stress, strain at work, high level of responsibility, irregular working hours, stress communicating with colleagues in parallel with many restrictions and rules related to strict labor discipline and bureaucratic procedures. Currently, the work of a civil servant is directly related to fast moving political events in Ukrainian society that continue to transform the country's political landscape, trigger socioeconomic changes and government reform. All of this increases the stress of their work load. The specifics of the profession and the peculiarities of the professional activ- ity of a civil servant can contribute to the development of pathological mental disorders, one of which is occupational burnout syndrome [1].

According to the World Health Organization, occupational burnout is a syndrome resulting from chronic work-related stress, with symptoms characterized by «feelings of energy depletion or exhaustion; increased mental distance from one's job, or feelings of negativism or cynicism related to one's job; and reduced professional efficacy» [2]. Burnout may influence health and contribute to the development of various psychosomatic diseases and addictive states. According to N. Vodopyanova [3], patients with burnout syndrome have a high probability of 
cardiovascular disease, weakening of the immune system, hormonal imbalance, accompanied by mood swings, insomnia, and alcohol abuse. The relationship between the frequency of hypertension and other cardiovascular diseases, in particular, coronary heart disease, with emotional stress at work was noted [3-6].

Occupational burnout as a mental disorder has been studied since the 1970s. Herbert Freudenberger became the first researcher to use the term «burnout» [7]. His research was based on his observations of volunteer staff (including himself) in a free drug clinic. He characterized burnout with a set of symptoms, including exhaustion caused by excessive demands at work, as well as physical symptoms such as headaches and insomnia, «speed of anger» and closed thinking [7].

Since then interest in occupational burnout increased, the syndrome became relevant and began to interest the scientists. It has been actively studying by various researches, including J. Greenberg [8], B. Perlman and E. Hartman [9], K. Maslach [10-12], M. Burish [13], as well as V. Boyko [14] and N. Vodopyanova [3], each of whom offered his own vision of problems, methods of definition and diagnosis of burnout syndrome.

Significant contribution to the study of burnout syndrome was made by American psychologists K. Maslach and S. Jackson [15-17]. Scientists invented diagnostic technique, the Maslach Burnout Inventory (MBI), that is currently the most widely used in the world [16, 17]. Accoding to K. Maslach and S. Jackson [15], burnout is a syndrome of physical and emotional exhaustion, which includes the development of negative self-esteem, negative attitudes toward work, loss of understanding and compassion for other people. They consider a three-dimensional construct that has three main components: emotional exhaustion, depersonalization and reduction of professional accomplishment. Emotional exhaustion manifests itself in a reduced emotional background, general exhaustion, feelings of desolation, chronic fatigue, constant general weakness and symptoms of depression. Emotional exhaustion is a major component of the syndrome, which is later projected on physical health and contributes to psychosomatic disorders and exacerbation of chronic diseases. Depersonalization is cynicism, indifference or a distant attitude towards work and colleagues. Reduction of professional accomplishment is characterized by the appearance of employees' feelings of incompetence and incompetence in their professional field, the message of the lack of it and the lack of their own achievements [11, 15-17].

The aim of the study was to investigate the presence and severity of the occupational burnout syndrome components in civil servants.

\section{MATERIAL AND METHODS}

A group of 100 civil servants aged 30 to 60 (mean age $41 \pm 7.7$ years; 63 (63\%) males and 37 (37\%) females) were randomly selected and examined. All the enrolled people participated in the regular medical check-up programs, and were free from severe chronic conditions. The Ukrainian version of MBI was used to diagnose the burnout syndrome. The MBI includes three scales: emotional exhaustion (9 items), depersonalization ( 5 items), and reduction of professional accomplishment ( 8 items). Each scale measures its own unique dimension of burnout. The level of severity of burnout on each scale was estimated by the sum of points (point could be from 0 to 6 ) on the corresponding items (Table 1) [16].

Scoring the Maslach Burnout Inventory (MBI)

\begin{tabular}{|l|c|c|c|}
\hline \multirow{2}{*}{\multicolumn{1}{c}{ The MBI Scales }} & \multicolumn{2}{c|}{ Burnout level, score } \\
\cline { 2 - 4 } & Low level & Medium level & High level \\
\hline Emotional exhaustion & $0-15$ & $16-24$ & $\geq 25$ \\
\hline Depersonalization & $0-5$ & $5-10$ & $\geq 10$ \\
\hline Reduction of professional accomplishment & $\geq 37$ & $31-36$ & $\leq 30$ \\
\hline
\end{tabular}

Software programs Statistica v. 12.6 and IBM SPSS Statistics v. 26.0 were used for statistical data analysis. Numeric variables were presented as $\mathrm{M} \pm \mathrm{SD}(\mathrm{M}-$ mean, $\mathrm{SD}$ - standard deviation) and $\mathrm{Me}(\mathrm{IQR})(\mathrm{Me}$ - median, IQR - interquartile range). Categorical variables were presented as absolute and relative (\%) frequency. In order to compare characteristics between two independent groups, we used Mann-Whitney U-test (for numeric variables) and $\chi^{2}$ test or Fisher's exact test (for categorical variables). In case of statistically significant difference in $\chi^{2}$ test, we used $\mathrm{z}$-test to compare the frequency of certain catego- ries of ordered categorical variables (in tables' columns). A 2-tailed $\mathrm{p}<0,05$ was considered statistically significant.

\section{RESULTS}

In general, medium to high levels of burnout for all the burnout syndrome components (emotional exhaustion, depersonalization, reduction of professional achievements) were found in $86(86,0 \%)$ people. Among them, $11(12,8 \%)$ respondents had a high level of each of these three burnout syndrome indicators. 
The distribution of the burnout syndrome components by the severity level is presented in Figure 1. Emotional exhaustion, being the primary component of the burnout syndrome, was the most frequent condition among the enrolled respondents (totally, 78 (78\%) people pointed at medium to high level of emotional exhaustion). De- personalization was the second most common condition with $65 \%$ of respondents (65 people) having its medium to high level. Reduction of professional accomplishment (medium to high level) was less common and registered in $54(54 \%)$ respondents.

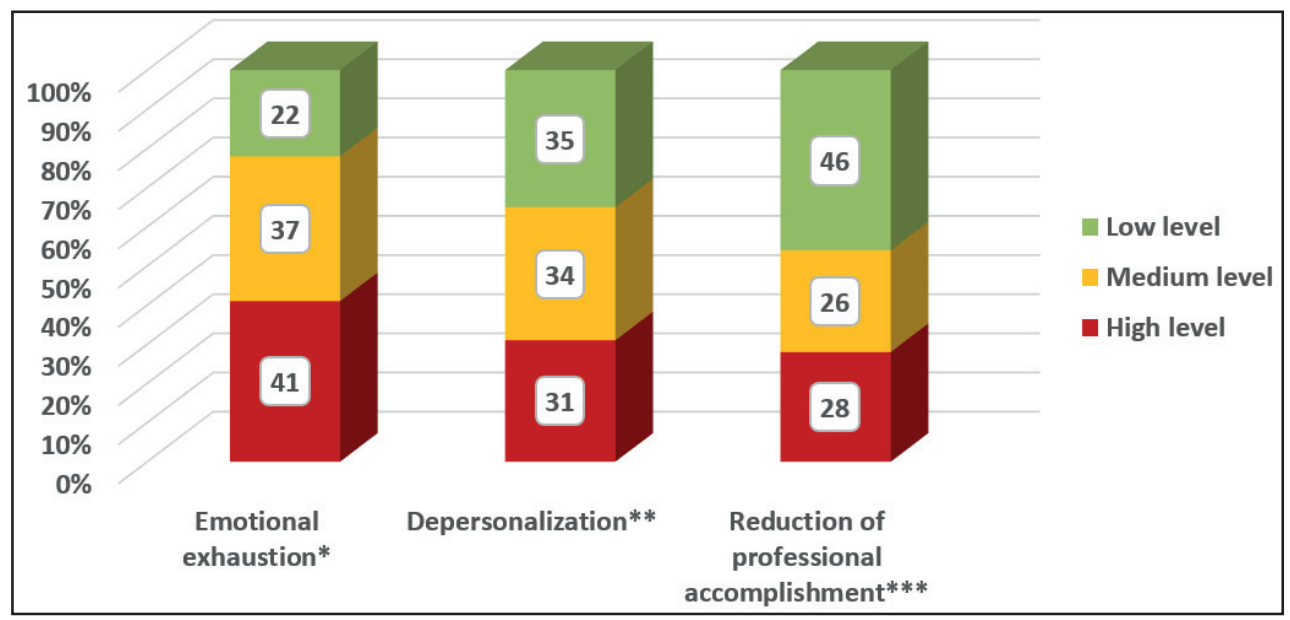

Figure 1. The structure of the burnout syndrome components by their severity $(\%)$ in the total sample of civil servants $(\mathrm{n}=100) . *$ the average

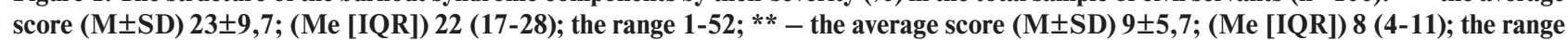
$0-25 ; * * *$ the average score $(M \pm S D) 34 \pm 7,0$; (Me [IQR]) 35 (29-40); the range 18-47

The analysis of gender characteristics of the occupational burnout revealed, that females were more vulnerable to emotional exhaustion and depersonalization, presenting the higher average value (Table 2), and the higher total frequency of medium to high level cases of that burnout syndrome component (Figure 2), as compared to males (namely, due to more frequent latter ones - see Table 3). At the same time, statistically significant gender differences in the average values and the structure of the other two burnout syndrome components (depersonalization and reduction of professional accomplishment) were not found.

Average values of the burnout components scores in males and females, Me (IQR)

\begin{tabular}{|c|c|c|c|}
\hline The MBI Scales & $\begin{array}{c}\text { Males } \\
\mathbf{n = 6 3}\end{array}$ & $\begin{array}{c}\text { Females } \\
\mathbf{n = 3 7}\end{array}$ & $\mathbf{p}$ \\
\hline Emotional exhaustion, score & $19(15-25)$ & $27(20-33)$ & $<0,001$ \\
\hline Depersonalization, score & $7(4-10)$ & $9(4-13)$ & 0,134 \\
\hline Reduction of professional accomplishment, score & $35(28-40)$ & $35(29-39)$ & 0,960 \\
\hline
\end{tabular}

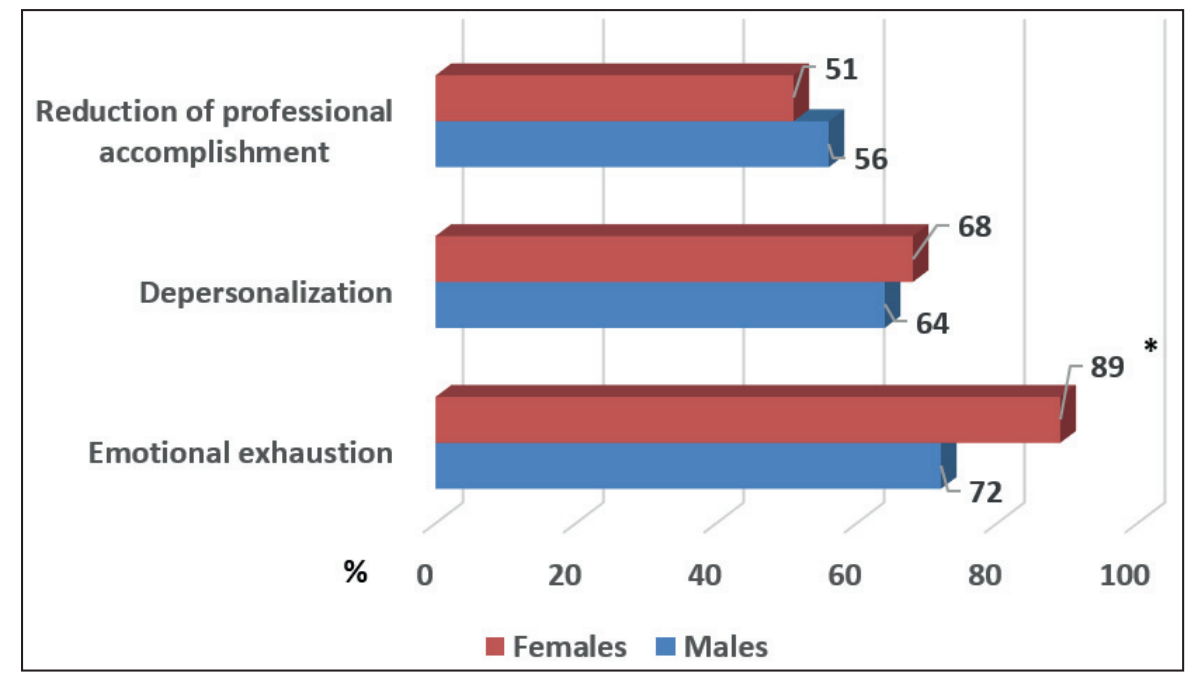

Figure 2. The total frequency of medium to high level cases of the burnout syndrome components in males and females. * $-p=0,047$ (Fisher's exact test) 
Severity degree of the burnout components in males and females

\begin{tabular}{|c|c|c|c|c|}
\hline \multicolumn{2}{|l|}{ Scales of the burnout syndrome } & $\begin{array}{c}\text { Males } \\
\mathrm{n}=63\end{array}$ & $\begin{array}{c}\text { Females } \\
\mathbf{n}=37\end{array}$ & p \\
\hline \multirow{3}{*}{ Emotional exhaustion, level, n (\%) } & Low $^{\mathrm{z}}$ & $18(28)$ & $4(11)$ & \multirow{3}{*}{0,027} \\
\hline & Medium & $25(40)$ & $12(32)$ & \\
\hline & $\operatorname{High}^{\mathrm{z}}$ & $20(32)$ & $21(57)$ & \\
\hline \multirow{3}{*}{ Depersonalization, level, n (\%) } & Low & $23(36)$ & $12(32)$ & \multirow{3}{*}{0,102} \\
\hline & Medium & $25(40)$ & $9(24)$ & \\
\hline & High & $15(24)$ & $16(43)$ & \\
\hline \multirow{3}{*}{ Reduction of professional accomplishment, level, n (\%) } & Low & $28(44)$ & $18(49)$ & \multirow{3}{*}{0,917} \\
\hline & Medium & $17(27)$ & $9(24)$ & \\
\hline & High & $18(29)$ & $10(27)$ & \\
\hline
\end{tabular}

Notes: * - Fisher's exact test; - statistically significant difference by z-test

Previously, it was thought that occupational burnout was more likely to occur in those employees who work with the human factor, affected people who work in the field of «man-to-man», and whose work was associated with constant communication (physicians, nurses, psychologists, teachers, police officers, managers, social workers) [6, 17].

We have established the high prevalence of occupational burnout in civil servants. The emotional exhaustion (namely, the medium to high severity level) was most common condition and manifested itself in a way of reduced emotional background, general exhaustion and a sense of desolation. Females were more predisposed to emotional exhaustion than males. The levels of emotional exhaustion in females were significantly higher. The second place in the structure of the emotional burnout of civil servants was taken by depersonalization - an indifferent and cynical attitude towards work and colleagues. Finally, the manifestation of reduction of professional accomplishment was the least frequent condition among enrolled civil servants.

Although the profession of civil servant is characterized by high communicative tension, it is not clearly a subject to the criteria of «man-to-man» [1]. More and more scientific papers have been beginning to refute this claim and do not limit the sphere of manifestation of occupational burnout. For example, it has been argued that burnout could occur in any profession, as well as outside it (for example, at home) [18].

Currently, the occupational burnout has been actively studied among civil servants because of high social significance of their work. For instance, S. Sokolovsky [19] noted the high tendency to occupational burnout in Ukrainian civil services, and S. Arefnia [20] studied the ways of prevention and correction of the burnout syndrome among civil servants of Ukraine. Nonetheless, the issues related civil servants' occupational burnout still remain unresolved and thus need further elucidation $[1,19,20]$.

\section{CONCLUSION}

The high prevalence of occupational burnout, namely its medium to high severity level, among the civil servants has been established, which indicates the urgency of the problem and the necessity for further research to find the causes, effective prevention measures, and ways to overcome the syndrome and restore the mental and physical health of civil servants.

Conflict of interest. The authors declare no conflict of interest related to this paper.

Sources of funding. The study was conducted as a fragment of the government-funded complex scientific project of the Scientific Department of Internal Medicine (State Institution of Science «Research and Practical Center of Preventive and Clinical Medicine» State Administrative Department) «Improvement of prevention, treatment and rehabilitation of patients with arterial hypertension and coronary heart disease with comorbid pathology in outpatient and inpatient settings» (state registration number 0119U001045; term: 2019-2021).

Compliance with ethical principles. The study was conducted in compliance with the principles of the Council of Europe Convention on Human Rights and Biomedicine (1997-2005), World Medical Association Declaration of Helsinki on the ethical principles for medical research involving human subjects (1964-2008), ICH-GCP Guideline, and current regulations of the Ministry of Health of Ukraine. The local ethics committee approved the study protocol. All persons signed an informed consent to participate in the study. 


\section{LITERATURE}

1. Арефнія С. В. Специфіка професійної діяльності державних службовців як один з чинників їх професійного вигорання. Актуальні проблеми психології: психологія обдарованості. Зб. наук. праць Інституту психології імені Г. С. Костюка НАПН України. Т. VI. Вип. 9. Київ, 2013. С. 71-81.

2. Burn-out an «occupational phenomenon»: International Classification of Diseases. WHO. 28 May 2019. Режим доступу: https://www.who.int/ news/item/28-05-2019-burn-out-an-occupationalphenomenon-international-classification-of-diseases\#: : text $=$ Burn\%2Dout \%20is\%20included\%20in, classified $\% 20 \mathrm{as} \% 20 \mathrm{a} \% 20$ medical $\% 20$ condition.\&text $=\% \mathrm{E} 2 \% 80 \% 9 \mathrm{CBurn} \% 2 \mathrm{Dout} \% 20 \mathrm{is} \% 20 \mathrm{a} \% 20$ syndrome, has\%20not\%20been\%20successfully\%20managed.

3. Водопьянова Н. Е., Старченкова Н. Е. Синдром выгорания. Диагностика и профилактика: практическое пособие. М.: Издательство Юрайт, 2017. 343 с.

4. Агапова Е. В., Винокур В. А., Болучевская В. В. Клинико-психологические характеристики профессионального выгорания у государственных служащих. Вестн. ВолгГМУ. 2013. № 2. С. 56-60.

5. Зинченко Ю. П., Первичко Е. И., Остроумова О. Д. Факторы, влияющие на формирование синдрома выгорания у пациентов с артериальной гипертензией на рабочем месте. Рациональная фармакотерапия в кардиологии. 2017. Т. 13. № 2. C. 213-220. DOI: https://doi.org/10.20996/18 19-6446-2017-13-2-213-220.

6. Комарова О. А. Синдром эмоционального выгорания как причина гипертонической болезни у лиц профессии типа «человек-человек». Евсевьевские чтения. Серия: актуальные проблемы специального и инклюзивного образования. Сборник научных трудов по материалам Международной научно-практической конференции с элементами научной школы для молодых ученых «51-е Евсевьевские чтения». Саранск: Мордовский государственный педагогический институт имени М. Е. Евсевьева. 2015. С. 52-57.

7. Freudenberger H. Staff burnout. JSI. Vol. 30 (1). P. 159-165. DOI: https://doi. org/10.1111/j.1540-4560.1974.tb00706.x.

8. Greenberg J. ISE Comprehensive stress management. McGraw-Hill Education, 2020. 480 p.
9. Perlman B., Hartman E. Burnout: Summary and Future Research. Human Relations. 1982. Vol. 35 (4). P. 283-305. doi:10.1177/001872678203500402.

10. Maslach C. Burnout: The Cost of Caring. Malor books, 2003. 302 p.

11. Maslach C, Leiter MP. Early predictors of job burnout and engagement. J Appl Psychol. 2008. Vol. 93 (3). P. 498-512. doi: 10.1037/0021-9010.93.3.498.

12. The Handbook of Stress and Health: A Guide to Research and Practice / Ed. by C. Cooper. J. Quick. John Wiley \& Sons, 2017. 728 p.

13. Burisch M. A. longitudinal study of burnout: The relative importance of dispositions and experiences. Work \& Stress. 2002. Vol. 16 (1). P. 1-17. https://doi. org/10.1080/02678370110112506.

14. Бойко В. В. Синдром «эмоционального» выгорания в профессиональном общении. СПб.: Питер, 1999. $105 \mathrm{c}$.

15. Maslach C., Jackson S. The measurement of experienced burnout. The measurement of experienced burnout. J Organ Behav. 1981. Vol. 2 (2). P. 99-113. DOI: https://doi.org/10.1002/job.4030020205.

16. Maslach C., Jackson S., Leiter M. Maslach Burnout Inventory: Third edition. In C. P. Zalaquett \& R. J. Wood (Eds.). Evaluating stress: A book of resources. Scarecrow education, 1997. P. 191-218.

17. Maslach C., Leiter M., Schaufeli W. Measuring burnout. In C. L. Cooper \& S. Cartwright (Eds.). The Oxford handbook of organizational well-being. Oxford: Oxford University Press. 2008. P. 86-108.

18. Bianchi R., Truchot D., Laurent E., Brisson R., Schonfeld I. Is burnout solely job-related? A critical comment. Scand J Psychol. 2014. Vol. 55 (4). P. 357-361. doi: 10.1111/sjop. 12119.

19. Соколовський С. I. Професійне емоційне вигоряння державних службовців: діагностика проблеми. Публічне адміністрування: теорія та практика: збірник наукових праць [Електронний ресурс]. 2010. № 10. Режим доступу: http://www.dridu.dp.ua/ zbirnik/2010-01/10ssisdp.pdf.

20. Арефнія С. В. Психологічні засоби профілактики та корекції професійного вигорання державних службовців законодавчого органу влади: дис. ... канд. психол. наук: 19.00.10 / Класичний приватний університет. Вищий навчальний заклад «Університет економіки та права «КРОК». Київ, 2018. 249 с.

\section{REFERENCES}

1. Arefnia, S. (2013). Spetsyfika profesiinoi diialnosti derzhavnykh sluzhbovtsiv yak odyn iz chynnykiv yikh profesiinoho vyhorannia [Specifics of profes- sional activity of civil servants as one of the factors of their occupational burnout]. Aktualni problemy psykholohii: psykholohiia obdarovanosti. Zb. nauk. prats 
Instytutu psykholohii imeni H. S. Kostiuka NAPN Ukrainy [Actual problems of psychology: the psychology of giftedness. The Collection of Scientific Papers of G. S. Kostyuk Psychology Institute of the NAES of Ukraine], 6 (9), 71-81. [In Ukrainian].

2. Burn-out an «occupational phenomenon»: International Classification of Diseases. WHO. 28 May 2019. Retrieved 01 June 2020, from: https://www.who.int/ news/item/28-05-2019-burn-out-an-occupationalphenomenon-international-classification-of-diseases\#: : text $=$ Burn $\% 2$ Dout $\% 20$ is $\% 20$ included $\% 20 \mathrm{in}$, classified $\% 20$ as $\% 20 \mathrm{a} \% 20$ medical $\% 20$ condition.\&tex$\mathrm{t}=\% \mathrm{E} 2 \% 80 \% 9$ CBurn\%2Dout\%20is\%20a\%20syndrome, has\%20not\%20been\%20successfully\%20managed.

3. Vodopyanova, N., Starchenkova, N. (2017). Sindrom vygoraniya: diagnostika i profilaktika [Burnout syndrome: diagnostics and prevention]. M.: Yurait Publisher, 343. [In Russian].

4. Agapova, E., Vinokur, V., Boluchevskaya, V. (2013) Kliniko-psikhologicheskie kharakteristiki professionalnogo vygoraniya u gosudarstvennykh sluzhashchikh [Clinical and psychological characteristics of professional burnout in civil servants]. Journal of Volgograd State Medical University, 2, 56-60. [In Russian].

5. Zinchenko, Yu, Pervichko, E., Ostroumova, O. (2017). Faktory, vliyayushchie na formirovanie sindroma vygoraniya u pacientov s arterial'noj gipertenziej na rabochem meste [Factors influencing the formation of burnout syndrome in patients with workplace hypertension]. Rational Pharmacotherapy in Cardiology, 13(2), 213-220. https://doi.org/10.20996/1819-644 6-2017-13-2-213-220. [In Russian].

6. Komarova, O.A (2015) Sindrom emocional'nogo vygoraniya kak prichina gipertonicheskoj bolezni u lic professii tipa «chelovek - chelovek» [Emotional burnout syndrome as a cause of hypertension in persons of the «man-to-man» type of profession]. Evsev'evskie chtenija. Serija: aktual'nye problemy special'nogo i inkljuzivnogo obrazovanija. Sbornik nauchnyh trudov po materialam Mezhdunarodnoj nauchno-prakticheskoj konferencii s jelementami nauchnoj shkoly dlja molodyh uchenyh «51-e Evsev'evskie chtenija» [Evsev'ev Readings. Series: Actual Problems of Special and Inclusive Education. Collection of scientific papers based on the materials of the International scientific-practical conference with elements of a scientific school for young scientists «The 51st Evsev'ev Readings»]. Saransk: M. Ye. Evsev'ev Mordovia State Pedagogical Institute, 52-57. [In Russian].

7. Freudenberger, H. J. (1974). Staff Burn-Out. Journal of Social Issues, 30(1), 159-165. https://doi. org/10.1111/j.1540-4560.1974.tb00706.x

8. Greenberg, J. S. (2020). Comprehensive stress management. McGraw-Hill Education, 480.

9. Perlman, B., \& Hartman, E. A. (1982). Burnout: Summary and Future Research. Hu- man Relations, 35(4), 283-305. https://doi. org/10.1177/001872678203500402.

10. Maslach, C. (2003). Burnout: The Cost of Caring. Malor books, 302.

11. Maslach, C., \& Leiter, M. P. (2008). Early predictors of job burnout and engagement. Journal of Applied Psychology, 93(3), 498-512. https://doi. org/10.1037/0021-9010.93.3.498.

12. Cooper, C. L., \& Quick, J. C. (2017). The handbook of stress and health: a guide to research and practice. John Wiley \& Sons, Inc., 728.

13. Burisch, M. (2002). A longitudinal study of burnout: The relative importance of dispositions and experiences. Work \& Stress, 16(1), 1-17. https://doi. org/10.1080/02678370110112506.

14. Boyko, V. V. (1999). Sindrom «jemocional'nogo» vygoranija v professional'nom obshhenii [The syndrome of «emotional» burnout in professional communication]. SPb.: Piter, 105. [In Russian].

15. Maslach, C., \& Jackson, S. E. (1981). The measurement of experienced burnout. Journal of Organizational Behavior, 2(2), 99-113. https://doi.org/10.1002/ job.4030020205.

16. Maslach, C., Jackson, S., Leiter, M. (1997). Maslach Burnout Inventory: Third edition. Evaluating stress: a book of resources. Scarecrow, 191-218.

17. Maslach, C., Leiter, M., Schaufeli, W. Measuring burnout. In Cartwright, S., \& Cooper, C. L. (2008). The Oxford handbook of organizational well-being. Oxford University Press, 86-108.

18. Bianchi, R., Truchot, D., Laurent, E., Brisson, R., \& Schonfeld, I. S. (2014). Is burnout solely job-related? A critical comment. Scandinavian Journal of Psychology, 55(4), 357-361. https://doi.org/10.1111/ sjop. 12119.

19. Sokolovskyi, S. I. (2010). Profesiine emotsiine vyhorannia derzhavnykh sluzhbovtsiv: diahnostyka problemy [Professional emotional burnout of civil servants: diagnosis of the problem]. Publichne administruvannia: teoriia ta praktyka: Elektronnyi zbirnyk naukovykh prats [Public administration: theory and practice: Electronic collection of scientific papers], 10. Retrieved from: http://www.dridu.dp.ua/zbirnik/2010-01/10ssisdp.pdf. [In Ukrainian].

20. Arefnia S.V. (2018). Psykholohichni zasoby profilaktyky ta korektsii profesiinoho vyhorannia derzhavnykh sluzhbovtsiv zakonodavchoho orhanu vlady: Dysertatsiia na zdobuttia vchenoho stupenia kandydata nauk [Psychological means of prevention and correction of professional burnout of civil servants of the legislative authority: PhD Thesis]. Kyiv Dysertatsiia na zdobuttia vchenoho stupenia kandydata nauk. Kyiv, 249. Retrieved from: https://library.krok.edu.ua/media/library/category/ disertatsiji-avtoreferati-vidguki/arefniia_2018-disertatsija.pdf. [In Ukrainian]. 


\section{Резюме}

\section{ОСОБЛИВОСТІ СИНДРОМУ ПРОФЕСІЙНОГО ВИГОРАННЯ У ДЕРЖАВНИХ СЛУЖБОВЦІВ}

\section{А. О. Іванчук, А. М. Кравченко, К. О. Міхалєв}

Державна наукова установа «Науково-практичний центр профілактичної та клінічної медицини» Державного управління справами, Київ, Україна

Мета: визначити наявність та оцінити ступінь вираженості компонентів синдрому професійного вигорання (СПВ) у державних службовців.

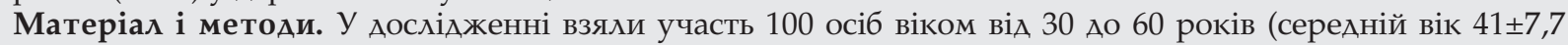
року; 63 (63\%) чоловіки 37 (37\%) жінок), вибірка яких була сформована за методом випадкового відбору. Усі обстежені були працівниками державної служби, перебували під диспансерним спостереженням, і не мали даних про тяжкі хронічні захворювання. Аля діагностики СПВ використано україномовну версію опитувальника MBI (Maslach Burnout Inventory).

Результати. У цілому, серед обстежених осіб середні та високі рівні професійного вигорання за всіма складовими синдрому (емоційна виснаженість, леперсоналізація, редукція професійних досягнень) були виявлені у 86 (86,0\%) осіб. Серед них в 11 (12,8\%) респондентів констатували високий рівень прояву СПВ за всіма трьома показниками. Найчастішим станом було емоційне виснаження, при цьому 78 (78\%) осіб вказували на середній чи тяжкий ступінь цього компоненту СПВ. Ознаки деперсоналізації середнього чи тяжкого ступеня зареєстровано у 65 (65\%) респондентів. Менш частим станом була редукція професійних досягнень, середній чи тяжкий ступені якої були зафіксовані у 54 (54\%) опитаних. При аналізі гендерних особливостей СПВ установлено більшу схильність жінок до емоційного виснаження, порівняно з чоловіками (вищий середній бал (медіана, міжквартильний інтервал) 27 (20-33) проти 19 (15-25), відповідно; $\mathrm{p}<0,001)$; частіше виявлення осіб з середнім чи тяжким ступенем вираженості цього компоненту СПВ (89\% проти 72\%, відповідно; $\mathrm{p}=0,047)$,- за рахунок випадків тяжкого ступеня [57\% vs. 32\%, відповідно; $\mathrm{p}=0,027])$.

Висновок. Установлено широку поширеність СПВ серед державних службовців, а саме з середнім чи високим ступенем вираженості його компонентів, що вказує на актуальність проблеми та необхідність подальших дослілжень для пошуку причин, ефективних заходів профілактики, шляхів подолання синдрому та вілновлення нервово-психічного потенціалу працівників державної служби.

Ключові слова: синдром професійного вигорання, державний службовець, емоційне виснаження, деперсоналізація, редукція професійних здібностей 


\section{Резюме}

\section{ОСОБЕННОСТИ СИНДРОМА ПРОФЕССИОНАЛЬНОГО ВЫГОРАНИЯ У ГОСУДАРСТВЕННЫХ СЛУЖАЩИХ}

\section{А. А. Иванчук, А. Н. Кравченко, К. А. Михалев}

Государственное научное учреждение «Научно-практический центр профилактической и клинической медицины» Государственного управления делами, Киев, Украина

Цель: определить наличие и оценить степень выраженности компонентов синдрома профессионального выгорания (СПВ) у государственных служащих.

Материал и методы. В исследовании приняли участие 100 человек в возрасте от 30 до 60 лет (средний возраст $41 \pm 7,7$ года; 63 (63\%) мужчин и 37 (37\%) женщин), выборка которых была сформирована методом случайного отбора. Все обследованные были работниками государственной службы, находились под диспансерным наблюдением, и не имели данных о наличии тяжелых хронических заболеваний. Аля диагностики СПВ использовали украиноязычную версию опросника МВI (Maslach Burnout Inventory).

Результаты. В целом, среди обследованных лиц средние и высокие уровни профессионального выгорания по всем составляющим синдрома (эмоциональная усталость, деперсонализация, редукция профессиональных достижений) были обнаружены в 86 (86,0\%) человек. Среди них у 11 (12,8\%) респондентов констатировали высокий уровень проявления СПВ по всем трем показателям. Частым состоянием было эмоциональное истощение, при этом 78 (78\%) человек указывали на среднюю или тяжелую степень этого компонента СПВ. Признаки деперсонализации средней или тяжелой степени зарегистрировано в 65 (65\%) респондентов. Менее частым состоянием была редукция профессиональных достижений, средняя или тяжелая степень которой была зафиксированы у 54 (54\%) опрошенных. При анализе гендерных особенностей СПВ установлено бо́лышую склонность женщин к эмоциональному истощению, по сравнению с мужчинами (более высокий средний балл (медиана, межквартильний интервал) 27 (20-33) против 19 (15-25), соответственно; р <0,001); более частое выявление лиц со средней или тяжелой степенью выраженности этого компонента СПВ (89\% против 72\%, соответственно; $\mathrm{p}=0,047)$,- за счет случаев тяжелой степени [57\% vs. 32\%, соответственно; $\mathrm{p}=0,027]) \cdot \chi$

Вывод. Выявлено широкую распространенность СПВ среди государственных служащих, а именно со средней или высокой степенью выраженности его компонентов, что указывает на актуальность проблемы и необходимость дальнейших исследований для поиска причин, эффективных мер профилактики, путей преодоления синдрома и восстановление нервно-психического потенциала работников государственной службы.

Ключевые слова: синдром профессионального выгорания, государственный служащий, эмоциональное истощение, деперсонализация, редукция профессиональных способностей

Інформація про авторів знаходиться на сайті http://www.cp-medical.com.

Дата надходження до редакцї-29.10.2020 